\title{
The theory of planned Behavior and Marketing Ethics Theory in Predicting Digital Piracy Intentions
}

\author{
AYI AHADIAT \\ Department of Management \\ University of Lampung \\ Bandar Lampung City \\ INDONESIA
RIBHAN
Department of Management
University of Lampung
Bandar Lampung City
INDONESIA

ALBET MAYDIANTORO

Department of Economic Education

University of Lampung

Bandar Lampung City

INDONESIA

\author{
FAJRIN SATRIA DWI KESUMAH \\ Department of Management \\ University of Lampung \\ Bandar Lampung City \\ INDONESIA
}

\begin{abstract}
This study discusses an interactive model that integrates behaviour theory with ethical theory to determine individual behaviour towards digital piracy. This study uses a quantitative approach by testing assumptions using the Structural Equation Model (SEM) assisted using the AMOS 4.0 application program. The results showed that the Theory of Planned Behavior (TPB) and the theory of marketing ethics (HV theory) could be used to predict the intention to commit digital piracy. Digital piracy intentions are not influenced by TPB's arbitrary rules, while digital piracy expectations and behaviour management significantly impact digital piracy intentions. Moral obligations and perceived benefits directly influence digital piracy. Moral obligation has clear negative effects, whereas perceived benefits positively impact piracy. Moral obligation hurts subjective value. Meanwhile, the perceived dangers often undermine individual attitudes towards digital piracy. The benefits people experience influence attitudes to digital piracy. This habit has had a dramatic and positive impact on digital piracy.
\end{abstract}

Key-Words: Planed behavior theory, marketing ethics theory, attitude, subjective norm, regulate perceived behavior, moral liability, fairness.

Received: February 12, 2021. Revised: April 1, 2021. Accepted: April 6, 2021. Published: April 12, 2021. 


\section{Introduction}

Social development is almost certainly the same as moral growth because moral behaviour, in general, is a fundamental element in the social act [1-3]. Moral development is based on moral reasoning and develop gradually $[4,5]$. Interior is a fundamental understanding of Kohlberg's moral development theory, particularly, the changes in behavioural development are controlled externally into behaviours controlled internally $[2,6]$. The theory is the view that moral reasoning is the basis of the conduct of ethical and unethical. Like for example, digital piracy by some experts viewed as unethical behaviour and detrimental to the producers and the state [7-10].

Copying or copying proprietary software or products, such as digital music or video files, illegal digital piracy [11-13]. Digital piracy is an important problem for developing the software industry and the digital media industry [14-16]. To restrict digital piracy, academics from various disciplines, such as business ethics, marketing, and IT, have also provided many models over the past 10 years to understand the nature of digital piracy and the driving forces behind individual digital piracy actions intentions.

The model is based on conduct theories like the predicted behavioural theory (TPB) [17] and ethical theories, including the general theory of marketing ethics [18] model of four ethical decision-making components [19]. While behavioural theory as TRA has been used by a large number of previous research on digital piracy $[16,20]$, Some researchers consider digital piracy to be unethical, as a basic theory to explain behaviour in connection with digital piracy [20], thus using ethical theory-based model decisionmaking.

Some researchers have started to factor ethics in the model. They are based on behavioural theory TRA and TPB [21-24]. For example, [25, 26] include factor in the ethics of individual moral responsibility in their model. [7, 27] in their study use individual moral besides moral responsibility TPB in determining influence intention to do digital piracy. While studies include ethical variables in their model, it is not easy to see a model completely integrated with theoretical behaviour and ethical theory [28-30].

This study confirmed research conducted by [20, $31]$ in testing an integrated model of the intent to undertake digital piracy to understand individuals' behaviour, a model combining behaviour theory and ethical theory. The difference is this research is a study did in Indonesia. The country of Indonesia is a developing country that the digital piracy rate is quite high at the moment.

The development of the software industry and the industrial growth of digital media have been greatly threatened by digital piracy. This may result in a revenue loss for the company and the country $[14,15,32]$. Behaviour digital piracy can occur because of the user's likely benefit, such as comfort, save time and money [33, 34]. This research is designed to test an integral model for understanding people's behavioural intentions in digital piracy. This model combines theoretical and theoretical behaviour empirically to predict digital piracy. The research issue (1) influences ethics dimensions such as schools of deontology and teleology (perceived benefits and perceived risks), subjective standards and individual intentions to piracy? (2) Does behavioural control perceive influence individual digital piracy intention? (3) Does the attitude against digital pirating and subjective standards meditate on consumers' intention to carry out digital piracy using deontological (moral and justice) and teleological (provincial and perceived risk) influence? (4) Do individual habits have an impact on individual digital piracy intention?

\section{Literature Review}

\subsection{Theory of Planned Behavior (TPB)}

Discussion about TPB beginning with discussing the theory of reasoned action (called TRA) for basic TPB is TRA $[35,36]$. TRA developed is a theory of attitude that often being researched and applied [37, 38]. Furthermore, the TRA is a theory known as the fundamental theory explaining behaviour. TRA is a parsimonious theory capable of explaining complex human behaviour $[39,40]$.

[41] revise the TRA into TPB by adding perceived behavioural control. Accommodate the main criticisms of the TRA about the behaviour of an easy or under the control of the willingness of the person. In fact, may face a person's behaviour with a situation that is not easy to behave, for example, due to less or no resources (e.g., money, time, skills, etc.) $[42,43]$.

Adding perceived behaviour control in TRA aims to clarify that intentions and behaviours are affected by human attitudes and subjective norms. However, it is also easily explained by whether or not someone is behaving. In other words, if one is sure that he does not have the resources (e.g., money), then that person is less likely to have the intention to buy a product even if the person has a positive attitude to buy the product [44-47]. 
Perceived behavioural control reflects well past experiences of a person, including obstacles and a hindrance to behave. Furthermore, perceived behavioural control may directly or may also influence behaviour through intention [41].

\subsection{Attitudes towards something}

A position on the evaluative dimension or bipolar behavioural effect is part of the planned behaviour theory [37, 48, 49]. Attitudes towards behaviours, which represent the consequences of such conduct, are dependent upon behavioural beliefs. Model theory of planned behaviour by multiplying quantifies the consequence of subjective probability that those consequences will occur if the behaviour is implemented by evaluating that consequence [5052].

\subsection{Subjective Norms}

Subjective standards are people's perceptions of social pressure of behaviour [41, 49, 53]. Subjective norms are based on normative beliefs in the model theory of rational action and theory of planned behaviour, which is the other party's preference for such actions to be carried out. The model quantifies these beliefs by multiplying the subjective probabilities of important other people (called referents) who believe that someone must perform that behaviour by someone's behaviour and follow their motives (the motivation to comply). These multiplication results are summed according to the existing referents $[54,55]$.

The division between attitudes and subjective norms seems to be done by consensus. The perception of one's influence on others is expressed as (a) comportemental beliefs and (b) normative beliefs $[41,56]$.

\subsection{Perceived Behavioral Control}

There is a determinant of motive in the model theory of expected conduct that does not form part of the model theory of rational acts assumed to have controlled behaviour. [41] includes the determinant to predict the behaviour intention is not under the full control of a person. Perceived behavioural control reflects behavioural challenges and reflects experience and hurdles [57-60]. Perceived behaviour control is the function of controlling beliefs, that is, beliefs about factors that contribute to or complicate the implementation of behaviour and the knowledge about these factors' strength [61-64]. Model theory of planned behaviour control quantifies subjective probability beliefs by multiplying the factors that complicate or simplify the implementation of behaviour by how far the factor can facilitate or complicate the implementation of behaviour (power of control belief or belief power control) [65-67].

\subsection{Marketing Ethic Theory (H-V Theory)}

Social development is almost certainly the same as moral growth because moral behaviour, in general, is a fundamental element in the social act $[2,3,68]$. Internalization is a basic understanding of the theory of moral development. In particular, behavioural development changes are controlled externally into behaviours controlled internally $[2,6,69]$. The theory believes that moral reasoning is the basis of behaviour unethical. In marketing, it is clarified by the theory Vitell Hunt and Vitell [70, 71] name marketing ethics theory or HV theory (Hunt-Vitell Theory). This theory has shown that there are different ethical gaps between marketers and consumers (such as the community's different needs and desires). H-V theory provides a positive framework for encouraging normative theory in explicit norms decision making, consequences, and decision rules in situations with ethical content and information about the possibility of the success of interventions offered to the company's progress more ethical. HV theory aims at (1) providing general morality decision theory and (2) providing process model theory. The $\mathrm{H}-\mathrm{V}$ model explores what a person's faces and considers the problem to be immoral. This theory will draw two schools of ethics in moral philosophy: deontological and teleological [72].

Deontological ethics, derived from the Greece word "deon" which means an obligation. Deontological ethics emphasize the obligation to act like a good man. According to this theory, the action is good not because doing so would bring a good result, but by the action itself as a good in itself. The person tests each alternative action's inherent accuracy or wrongdoing in the ontology evaluation process [73-75]. This process compares each alternative behaviour with a series of norms predetermined by the ontology. These principles are personal or ethical laws, ranging from (1) the general views on integrity, stealing, fraud, etc., and deal with people on fairness (2) issues: opinions about misguided ads, the protection of the goods, "bribery" information confidentiality, interviewer's name and interviewer's dishonesty $[76,77]$.

Teleological ethics, derived from the Greece word "telos", meaning goals, objectives, effects, and results. According to this theory, an action is good if 
it is well-intentioned and brings good results, and useful for all parties [78-80]. The teleology of the assessment process concentrates on four structures: (1) the effects of each alternative action of various stakeholders; (2) potential consequences which in each stakeholder community; (3) the value of each stakeholder group, whether willing or unwilling; (4) Each individual and circumstance can differ in the identity and significance of stakeholder groups.

Hunt-Vitell Theory (Theory of Marketing Ethics) was introduced in 1986 and revised in 1993 due to the evaluation of the researchers of the previous model. Many researchers can accept this model as a base to expand the body of knowledge about the process of ethical decision-making in business in general and marketing in particular [72]. A type of ethics decision-making (EDM) is the HuntVitell model (HV). Therefore, the model's steps should be seen as a procedure or course of action that occurred [72]. As a process, stage models can be explained and understood as a means or method of ethical decision-making. HV model is the theory of (positive) descriptive, describing the approach of reasonable action to the ethical decision-making process [81-83]. In reasoned action, the ethical decision-making process is considered rational and subjective based on the norms of behaviour and moral considerations relevant influence. The decision-makers assess alternative courses of action or behaviour in analyzing them carefully and cautiously before reaching the desired goal. The value system would affect the choice of ethical decisions [84-86].

Implementation of this theory in marketing is to establish and maintain long-term relationships that are responsible, and companies must pay attention to the ethical issues of marketing and business. For this reason, ethics and ethical assessment are at the core of the most ethical decision-making model in the marketing field, including the intention to use pirated software [72]. In the HV model, moral judgment and intentional morality must be better predictors of behaviour when moral issues are significant as the theoretical basis and focus on the importance of morality and the intensity of moral issues as the key to understanding morality when the content is intended to be ethical.

TPB model of behavioural intentions affects pirated products [87-89]. Individual attitudes toward piracy software (pirated products) reflect the personal attitudes of that behaviour's results. If an individual has a strong tendency towards pirated products, he will probably intend to use a pirated product.
Conversely, if a person has a weak tendency towards pirated products, they will tend to have an intention not to use pirated products $[12,90,91]$.

Subjective norms relating to individual intention to use pirated software $[92,93]$. In other words, the level of social stress that people feel about their actions is subjective criteria. If people who personally think that are important to him think that pirated products or using pirated products are not a big deal, then the individual will have a higher willingness to use pirated products.

Perception of behavioural control in this study refers to the technical control over the individual's perception of product piracy. As a result, when consumers perceive that he has control over behaviour against piracy products, they intend to use pirated products positively. [72] Comply with ethical standards in model making. This model is a general ethical marketing paradigm that focuses on people's thought method. This shows that when someone finds a problem with content morality, the moral considerations determined by the argumentative and teleological evaluation of the problem, and then the moral judgment of morality's impact on personal behaviour intentions. Some researchers have used moral decision theory as the theoretical background of digital piracy research [94-96].

TPB said that some comportment variables are decided by actions that should follow, and comportment has three predictions: behavioural, subjective expectations and perceived behavioural regulation [97-99]. Therefore, we also apply the theory to the subjective expectations of digital piracy, digital piracy behaviours, and behaviour management perceived.

Assumption 1: Subjective digital piracy laws would have a beneficial effect on people's intention to enforce digital piracy.

Assumption 2: Attitudes towards digital piracy hurt personal behaviour and conduct digital piracy.

Assumption 3: Understanding behaviour management positively influences human behaviour Digital piracy intentions.

In parallel with attitude, subjective norm and behaviour mediated interpretation, in contextual behaviour unethical a moral obligation is expected [41]. Moral responsibility is an important predictor of intent to commit digital piracy $[7,20,100]$. The subjective norm is the belief in the result that regulates someone and gets encouragement from this reference [49]. Moral responsibility as standard 
ethics normative may have a role in shaping conviction normative individual.

Assumption 4: Negative moral responsibility will affect employees' behavioural intentions, personal digital piracy.

Assumption 5: Negative moral responsibility will affect digital piracy's personal subjective norms.

To safeguard society, justice has a universal moral function and offers standard ethics to differentiate between right and wrong. Justice can also influence individuals' subjective expectations of digital piracy.

Assumption 6: the effects of justice on digital piracy's personal subjective standards would be negative.

[72] argued that the teleological evaluation affects ethical judgment on behaviour; thus, there is a perceived consequence of each alternative behaviour as stakeholders. Therefore, we noticed that the consequences of perception influence the evaluation of teleological behaviours by behaviours and attitudes. Therefore, the assumption that rewards are beneficial outcomes can have a huge effect on people's behaviours and intentions.
Assumption 7: Perceived benefits will positively influence individual attitudes toward digital piracy behaviour.

Assumption 8: Perceived advantages would positively impact individual behavioural intentions to piracy.

The perceived danger can be seen as perceptions of the negative effects. The perceived risks have been found to influence the decision-making process of consumer piracy $[15,101]$. If piracy triggers risk perception, the individual's attitudes to digital piracy would be negatively affected.

Assumption 9: Perceived danger would have a detrimental impact on individual behaviours.

Customization refers to level situational habits that may occur independently. This is dependent on the knowledge and willingness of someone to perform a certain mission $[102,103]$. According to [104, 105], habits affect individual behaviour and a person's attitude. [106, 107] showed that custom influences attitude individual against piracy.

Assumption 10: Habits will affect attitude individuals against digital piracy positively.

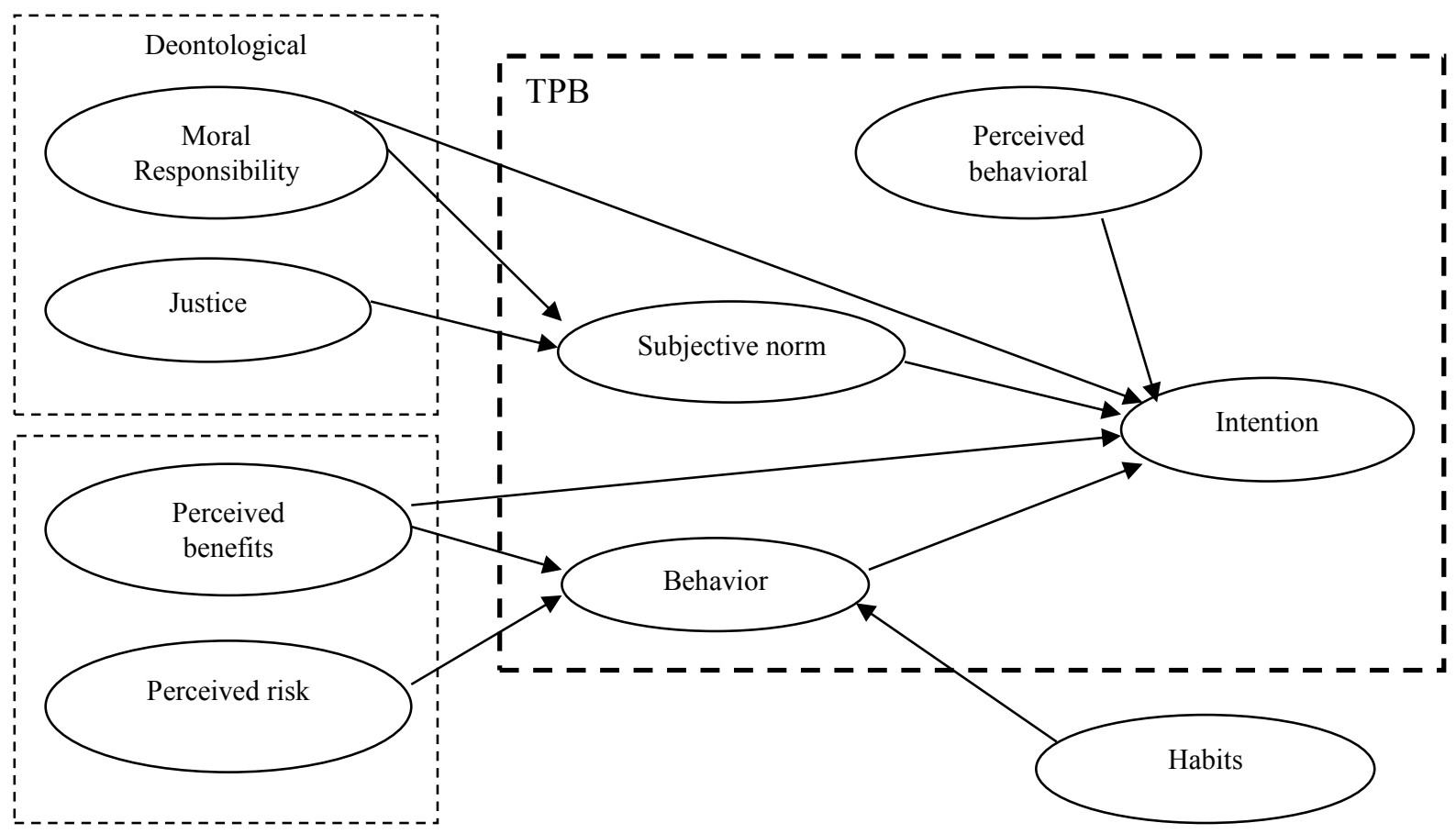

Figure 1: Research Model

\section{Methods}


A quantitative approach is taken in this analysis by testing the assumption using Structural Equation Models (SEM) assisted using the AMOS 4.0 program application.

\subsection{Sample}

The samples are staff and students of the Faculty of Economics and Business (FEB), University of Lampung. The survey method was carried out using a simple random sampling process, meaning that everyone at FEB has the same opportunity to become a resource. The number of samples is 450 employees and male students and female students.

\subsection{Measurement of Research Variables}

The method of measuring attitudes towards digital piracy, subjective norms, controlling behaviour and piracy intentions in TPB is based on moral obligations and acts of justice. Measured perceived benefits and perceived risks based on the study's measured value determined by a Likert scale (strongly disagree $=1$ to agree strongly $=5$ ) displayed across all measurement objects.

The validity test was carried out using factor analysis techniques. This is intended to measure how well an instrument. A valid measurement scale is the scale measure expected to be measured [108]. The key aspect of effectiveness in this study is to construct effectiveness. The validity of a construction is the extent to which a collection of measuring elements represents the basic component of theory for measurement [108]. Empirical rules for constructing validity: (1) The estimated standard load should be 0.5 or higher, (2) The extracted mean square error should be 0.5 or more, (3) The mean difference between the two factors has to be greater than these two factors and (4) the construction reliability must be 0.7 or higher.

Table 1. Factor Loading Research Variable

\begin{tabular}{|l|c|}
\hline \multicolumn{1}{|c|}{ Variable } & Loading Factor \\
\hline Moral Responsibility & 0,578 \\
\hline Justice & 0,500 \\
\hline Perceived benefits & 0,636 \\
\hline Perceived risk & 0,689 \\
\hline Regulation of actions perceived & 0,509 \\
\hline Standard subjective & 0,443 \\
\hline Attitude & 0,708 \\
\hline Habits & 0,783 \\
\hline Intention to Use & 0,500 \\
\hline
\end{tabular}

Instrument reliability is the instrument measurement's pertinence or accuracy [109]. Reliability tests performed to determine the consistency and accuracy of measurement when the measurement is done at the same object over and over again with the same instrument [110]. Coefficient
Cronbach Alpha indicates reliability testing. Getting closer to 1.00 , the higher the consistency of the answers to score grains have a question or a more trustworthy, less reliability of 0.6 is not good enough, acceptable 0.7 and above 0.8 is good.

Table 2. Cronbach Alpha Variable

\begin{tabular}{|l|c|c|}
\hline \multicolumn{1}{|c|}{ Research variable } & Cronbach Alpha & Reliable Item questions \\
\hline Moral Responsibility & 0,844 & 4 items \\
\hline Justice & 0.931 & 2 item \\
\hline Perceived benefits & 0.904 & 2 item \\
\hline Perceived risk & 0.865 & 3 items \\
\hline Regulation of actions perceived & 0.682 & 2 item \\
\hline Standard subjective & 0.546 & 2 item \\
\hline Attitude & 0,849 & 3 items \\
\hline Habits & 0.945 & 4 items \\
\hline Intention to Use & 0.912 & 2 item \\
\hline
\end{tabular}


To analyze this analysis with the aid of an application software AMOS 4.0 using the Structural Equation Model (SEM) technique.

\section{Result Research and Discussion}

The questionnaire was distributed 450 questionnaires and return as many as 413 respondents (response rates of 92\%). Of the 413 questionnaires contained, 10 questionnaires were not complete, and respondents' identity has left her not filled so that the number of questionnaires that can be processed or analyzed is as many as 403 questionnaires. Characteristics of respondents by sex are dominated by male respondents as many as 267 respondents $(66 \%)$, while respondents by age dominated between the ages of 21-30 years as many as 178 respondents or $42 \%$. Characteristics respondents based on education show that employees and students at the University of Lampung are dominated by education Strata 1 (S1) or students of the final year as many as 215 people or $53 \%$. Thus, more than half of the employees and students used as a sample were undergraduate students.

The presumption that subjective standards against digital pirates positively affected people's digital piracy intentions was not verified. Intent digital piracy is adversely affected by subjective legislation, but the impact is not significant (estimated -04, p-value 0.58). This means that among (family, friends and nearby people), the better the subjective norms, the more respondents will not conduct piracy, and vice versa.

The second assumption indicates that digital piracy behaviours would adversely affect people's digital piracy intentions (estimated value of 0.17 , the $\mathrm{p}$-value of 0.01). The interviewee's attitude is better, so the interviewee has no intention of digital piracy, which is the case.

The third assumption pointed to the positive influence of the perception of conduct regulation on the individual conduct's intention to enforce digital pirating and saw this evidence (estimated at 0.22 , the $\mathrm{p}$-value is 0.00 ). The positive understanding of behavioural regulation can affect digital piracy's individual behavioural intentions.

In the 4th assumption, moral responsibility would harm the person's intention to carry out digital piracy $(0,06$ estimate, $p$-value 0.42$)$. Although there is a negative moral obligation affecting the intent of digital piracy, it does not matter. Similarly, the moral obligation has a detrimental influence on the purpose of piracy and does not have an important impact on the fifth presumption ( $\mathrm{p}$-value estimates $-0,11$ and $0,15)$. Accordingly, conclusions 4 and 5 do not matter.

Allegations of justice will negatively impact individual subjective norms to do digital piracy in assumption 6, Statistically are not proven (estimate 0,05 and p-value 0,53). All six hypotheses are not supported.

Assumption 7 that the perceived benefits would have a favourable and negligible effect on individual attitudes to digital piracy ( $\mathrm{p}$-value estimate of 0,06 and 0,33 ). The effect of perceived favourable and exceedingly limited.

Assumption 8: the perceived benefits that will affect individual behaviour intention to commit digital piracy is positive and significant ( $p$-value estimate of 0,31 and 0,00 ), proved statistically. Individuals feel the benefits of digital piracy intention positively. They did piracy behaviour because they feel the benefits for their purposes.

Assumption ninth states that the perceived risk will negatively influence individual attitudes toward digital piracy, not significant (-0.09 estimate and pvalue 0.13 ). This shows that when they do digital piracy negatively, it will be at risk. The greater the risk posed by piracy, the less likely they are to commit digital piracy.

On the tenth assumption, allegations against habits will influence individual attitudes toward digital piracy positively (estimate 0.56 and p-value 0.00 ), proved statistically. Individuals who are used to being highly engaged in digital piracy will also have great digital piracy intentions. A description of the research hypotheses is given in Table 3 below.

Table 3. Study assumption overview

\begin{tabular}{|l|c|c|c|}
\hline \multicolumn{1}{|c|}{ Assumption } & Estimate & $p$-value & Result \\
\hline Assumption 1 & $-0,04$ & 0,58 & Not Support \\
\hline Assumption 2 & $-0,17$ & 0,01 & Support \\
\hline Assumption 3 & 0,22 & 0,00 & Support \\
\hline Assumption 4 & $-0,06$ & 0,42 & Not Support \\
\hline Assumption 5 & $-0,11$ & 0,15 & Not Support \\
\hline
\end{tabular}




\begin{tabular}{|l|c|c|c|}
\hline Assumption 6 & 0,05 & 0,53 & Not Support \\
\hline Assumption 7 & 0,06 & 0,33 & Not Support \\
\hline Assumption 8 & 0,31 & 0,00 & Support \\
\hline Assumption 9 & $-0,09$ & 0,13 & Not Support \\
\hline Assumption 10 & 0,56 & 0,00 & Support \\
\hline
\end{tabular}

This study proposes an integrated model that blends TPB and moral theory. The theory is often used when investigating digital piracy or pirated goods and a model of 10 false and empirically checked hypotheses. All hypotheses have been tested by SEM and provided the necessary support for the proposed model, as shown in Figure 2.

The subjective norms of TPB will not affect the intention of digital piracy. The perception of control behaviours and attitudes will affect the intention of piracy. This study's results are different from those of Chinese graduate students [111]. Her findings indicate that TPB is not very different from moral theory in predicting digital piracy intent.

Moral responsibility directly affects the intention and (path coefficient -0.06) of digital piracy. This means that digital piracy is considered unethical behaviour, such as cheating in tests or exams, cheating, making counterfeit products, etc. It has also been found that moral responsibility is the factor most likely to influence the intent of digital piracy. These results are supported by research [111, 112].

The results show that the perceived benefits and risk have a substantial effect on attitudes towards digital piracy due to this practice. The results show that the previous piracy studies' findings are clear $[111,113,114]$. The perceived advantages influence the purpose of introducing digital piracy in particular. This implies that the deviation from certain forms of behaviour is the product of certain decisions [81].

Habits have shown a significant effect on digital piracy attitudes (path coefficient of 0.56 ). The social and economic changes are likely to change consumer behaviour and changes in digital media habits due to the negligence and destruction of self-regulation.

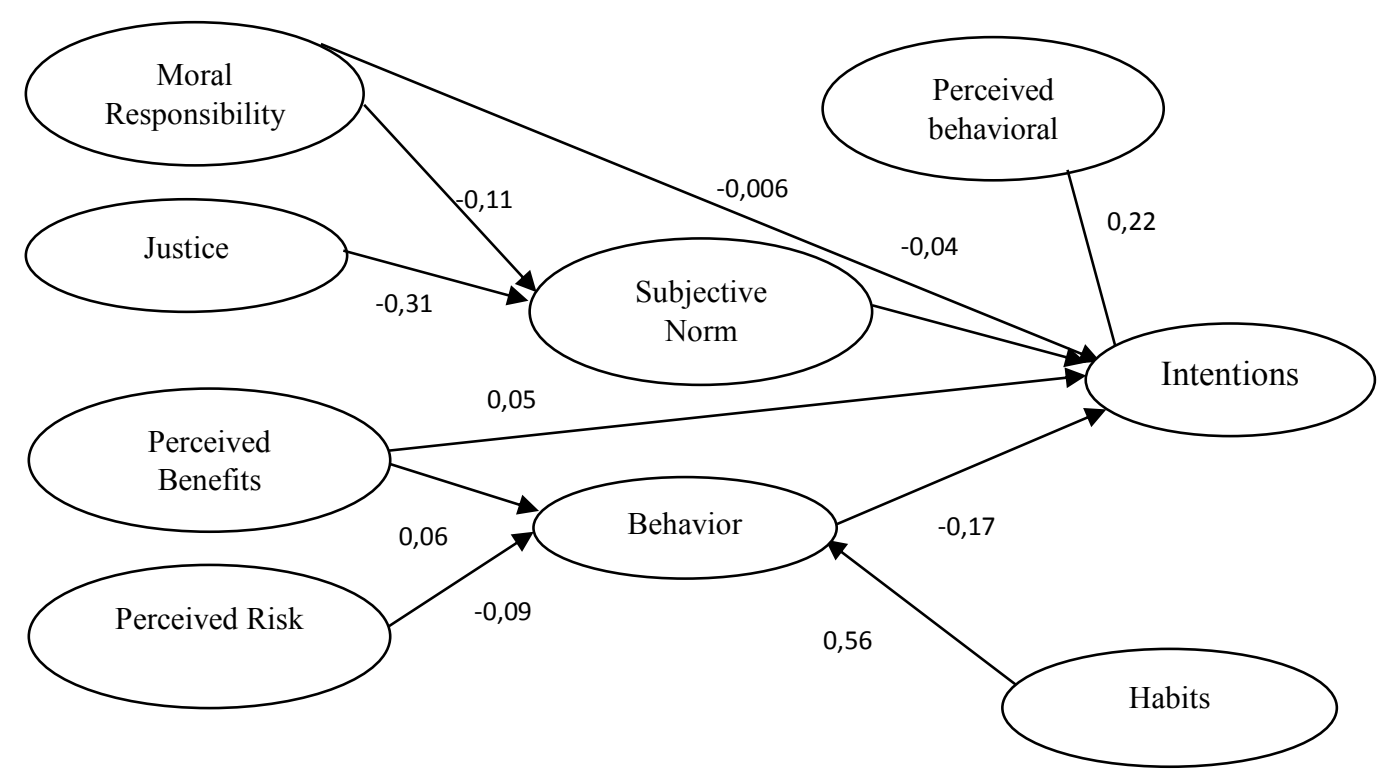

Figure 2. Model for Outcome Research

\section{Conclusion}

This analysis to know the two Theories of Planning Action (TPB) and the Integrated Marketing Ethics Theory (HV Theory). The goals of digital piracy are predictable. The subjective criteria in the TPB are not intended to influence digital piracy. They substantially influence digital piracy's aims on attitudes towards digital piracy and behavioural control interpretations. The intention to introduce digital piracy directly affects moral accountability and perceived benefits. Moral accountability has a strong negative impact, while the perceived benefits have on digital piracy. Moral responsibility destroys arbitrary expectations. Simultaneously, perceived 
threats often break personal habits. The perceived advantage has a positive effect on the attitude of digital piracy. Attitudes towards digital piracy have had a positive and important impact.

\section{References}

[1] Gintis, H., Individuality and entanglement: the moral and material bases of social life. 2016: Princeton University Press.

[2] Gibbs, J.C., Moral development and reality: Beyond the theories of Kohlberg, Hoffman, and Haidt. 2019: Oxford University Press.

[3] Ellemers, N., Morality and the regulation of social behavior: Groups as moral anchors. 2017: Psychology Press.

[4] Rutland, A. and M. Killen, A developmental science approach to reducing prejudice and social exclusion: Intergroup processes, social-cognitive development, and moral reasoning. 2015. 9(1): p. 121-154.

[5] Dahl, A. and M. Killen, Moral reasoning: Theory and research in developmental science. 2018. 4: p. 1-31.

[6] Karmakar, R., Does parenting style influence the internalization of moral values in children and adolescents? 2015. 60(4): p. 438-446.

[7] Hashim, M.J., K.N. Kannan, and D.T. Wegener, Central role of moral obligations in determining intentions to engage in digital piracy. 2018. 35(3): p. 934-963.

[8] Arli, D. and F. Tjiptono, Consumer digital piracy behaviour among youths: insights from Indonesia. 2016.

[9] Surdam, D.G., You can't live (well) without business ethics, in Business Ethics from Antiquity to the 19th Century. 2020, Springer. p. 1-14.

[10] Meshref, H., Predicting Loan Approval of Bank Direct Marketing Data Using Ensemble Machine Learning Algorithms. International Journal of Circuits, Systems and Signal Processing, 2020. 14: p. 9.

[11] Tomczyk, Ł., The Practice of Downloading copyrighted files among adolescents in Poland: Correlations between piracy and other risky and protective behaviours online and offline. 2019. 58: p. 101137.

[12] Arli, D., F. Tjiptono, and R. Porto, The impact of moral equity, relativism and attitude on individuals' digital piracy behaviour in a developing country. 2015.

[13] Tjiptono, F. and D. Arli, Gender and digital privacy: Examining determinants of attitude toward digital piracy among youths in an emerging market. 2016. 40(2): p. 168-178.

[14] Aversa, P., A. Hervas-Drane, and M. Evenou, Business model responses to digital piracy. 2019. 61(2): p. 30-58.

[15] Koklic, M.K., M. Kukar-Kinney, and I. Vida, Three-level mechanism of consumer digital piracy: Development and cross-cultural validation. 2016. 134(1): p. 15-27.

[16] Pham, Q.T., N.M. Dang, and D.T. Nguyen, Factors affecting on the digital piracy behavior: an empirical study in Vietnam. 2020. 15(2): p. 122-135.

[17] Conner, M., Theory of planned behavior. 2020: p. 1-18.

[18] Jafarkarimi, H., et al., Behavioral intention in social networking sites ethical dilemmas: An extended model based on theory of planned behavior. 2016. 62: p. 545-561.

[19] Schwartz, M., Ethical decision-making theory: An integrated approach. 2016. 139(4): p. 755776.

[20] Lowry, P.B., J. Zhang, and T. Wu, Nature or nurture? A meta-analysis of the factors that maximize the prediction of digital piracy by using social cognitive theory as a framework. 2017. 68: p. 104-120.

[21] Cronan, T.P., J.K. Mullins, and D.E. Douglas, Further understanding factors that explain freshman business students' academic integrity intention and behavior: Plagiarism and sharing homework. 2018. 147(1): p. 197220.

[22] Liu, X., et al., Psychological and demographic factors affecting household energy-saving intentions: a TPB-based study in Northwest China. 2020. 12(3): p. 836.

[23] Yazdanpanah, M. and M. Forouzani, Application of the Theory of Planned Behaviour to predict Iranian students' intention to purchase organic food. 2015. 107: p. 342-352.

[24] Gu, D., et al., Social media-based health management systems and sustained health engagement: TPB perspective. 2019. 16(9): $\mathrm{p}$. 1495.

[25] Pohling, R., et al., What is ethical competence? The role of empathy, personal values, and the 
five-factor model of personality in ethical decision-making. 2016. 137(3): p. 449-474.

[26] Wang, L.C. and L. Calvano, Is business ethics education effective? An analysis of gender, personal ethical perspectives, and moral judgment. 2015. 126(4): p. 591-602.

[27] Chen, M.-F., Extending the theory of planned behavior model to explain people's energy savings and carbon reduction behavioral intentions to mitigate climate change in Taiwan-moral obligation matters. 2016. 112: p. 1746-1753.

[28] Preece, D., et al., Establishing the theoretical components of alexithymia via factor analysis: Introduction and validation of the attentionappraisal model of alexithymia. 2017. 119: $\mathrm{p}$. 341-352.

[29] Hoch, J.E., et al., Do ethical, authentic, and servant leadership explain variance above and beyond transformational leadership? A metaanalysis. 2018. 44(2): p. 501-529.

[30] Lehnert, K., Y.-h. Park, and N. Singh, Research note and review of the empirical ethical decision-making literature: Boundary conditions and extensions. 2015. 129(1): p. 195-219.

[31] Koay, K.Y., Understanding consumers' purchase intention towards counterfeit luxury goods: An integrated model of neutralisation techniques and perceived risk theory. 2018.

[32] Fink, C., K.E. Maskus, and Y. Qian, The economic effects of counterfeiting and piracy: A review and implications for developing countries. 2016. 31(1): p. 1-28.

[33] Arli, D., et al., Religiousness and digital piracy among young consumers in an emerging market. 2017.

[34] Burruss, G. and C. Dodge, 10 The criminality of digital piracy. 2018: p. 208.

[35] Paul, J., A. Modi, and J. Patel, Predicting green product consumption using theory of planned behavior and reasoned action. 2016. 29: p. 123-134.

[36] Al-Suqri, M.N. and R.M. Al-Kharusi, Ajzen and Fishbein's theory of reasoned action (TRA)(1980), in Information seeking behavior and technology adoption: Theories and trends. 2015, IGI Global. p. 188-204.

[37] Montaño, D.E. and D. Kasprzyk, Theory of reasoned action, theory of planned behavior, and the integrated behavioral model. 2015. 70(4): p. 231.
[38] Lai, P., The literature review of technology adoption models and theories for the novelty technology. 2017. 14(1): p. 21-38.

[39] Shiau, W.-L. and P.Y. Chau, Understanding behavioral intention to use a cloud computing classroom: A multiple model comparison approach. 2016. 53(3): p. 355-365.

[40] Tarhini, A., N.A.G. Arachchilage, and M.S. Abbasi, A critical review of theories and models of technology adoption and acceptance in information system research. 2015. 6(4): p. 58-77.

[41] Ajzen, I., The theory of planned behavior: Frequently asked questions. 2020. 2(4): p. 314-324.

[42] Leary, M.R., Self-presentation: Impression management and interpersonal behavior. 2019: Routledge.

[43] Weaver, R.K., Getting people to behave: Research lessons for policy makers. 2015. 75(6): p. 806-816.

[44] McCormick, K., Celebrity endorsements: Influence of a product-endorser match on Millennials attitudes and purchase intentions. 2016. 32: p. 39-45.

[45] Yadav, R. and G.S. Pathak, Young consumers' intention towards buying green products in a developing nation: Extending the theory of planned behavior. 2016. 135: p. 732-739.

[46] Hsu, C.-L., C.-Y. Chang, and C. Yansritakul, Exploring purchase intention of green skincare products using the theory of planned behavior: Testing the moderating effects of country of origin and price sensitivity. 2017. 34: p. 145-152.

[47] Abd Rahman, A., E. Asrarhaghighi, and S. Ab Rahman, Consumers and Halal cosmetic products: knowledge, religiosity, attitude and intention. 2015.

[48] De Leeuw, A., et al., Using the theory of planned behavior to identify key beliefs underlying pro-environmental behavior in high-school students: Implications for educational interventions. 2015. 42: p. 128138.

[49] Ajzen, I., Consumer attitudes and behavior: the theory of planned behavior applied to food consumption decisions. 2015. 70(2): p. 121138.

[50] Lopes, J.R.N., et al., A new model for assessing industrial worker behavior regarding energy saving considering the theory of planned 
behavior, norm activation model and human reliability. 2019. 145: p. 268-278.

[51] Roos, D. and R. Hahn, Understanding collaborative consumption: An extension of the theory of planned behavior with valuebased personal norms. 2019. 158(3): p. 679697.

[52] Rezaei, R., M. Seidi, and M. Karbasioun, Pesticide exposure reduction: extending the theory of planned behavior to understand Iranian farmers' intention to apply personal protective equipment. 2019. 120: p. 527-537.

[53] Shin, Y.H. and M. Hancer, The role of attitude, subjective norm, perceived behavioral control, and moral norm in the intention to purchase local food products. 2016. 19(4): p. 338-351.

[54] Cooper, G., Using an extended theory of planned behaviour model to investigate students' intentions to enrol in university. 2016.

[55] Sussman, R., Paved with good environmental intentions: reconsidering the theory of planned behaviour. 2015.

[56] Chan, D.K.C., et al., Modal salient belief and social cognitive variables of anti-doping behaviors in sport: Examining an extended model of the theory of planned behavior. 2015. 16: p. 164-174.

[57] Kiriakidis, S., Perceived behavioural control in the theory of planned behaviour: variability of conceptualization and operationalization and implications for measurement, in Strategic Innovative Marketing. 2017, Springer. p. 197202.

[58] Utami, C.W., Attitude, subjective norm, perceived behaviour, entrepreneurship education and self efficacy toward entrepreneurial intention university student in Indonesia. 2017.

[59] Kiriakidis, S., Theory of planned behaviour: The intention-behaviour relationship and the perceived behavioural control (PBC) relationship with intention and behaviour. 2015. 3(2): p. 40-51.

[60] Lu, Y.-C. and K.-N. Chen, Consumer knowledge, brand image, openness to experience and involvement: a case in cosmetic consumption. 2017. 7(04): p. 349.

[61] Kim, E., et al., The roles of attitude, subjective norm, and perceived behavioral control in the formation of consumers' behavioral intentions to read menu labels in the restaurant industry. 2013. 35: p. 203-213.
[62] Kim, Y. and $\mathrm{H}$. Han, Intention to pay conventional-hotel prices at a green hotel-a modification of the theory of planned behavior. 2010. 18(8): p. 997-1014.

[63] Chen, C.-f., X. Xu, and J.K. Day, Thermal comfort or money saving? Exploring intentions to conserve energy among lowincome households in the United States. 2017. 26: p. 61-71.

[64] Brown, T.J., S.H. Ham, and M. Hughes, Picking up litter: An application of theorybased communication to influence tourist behaviour in protected areas. 2010. 18(7): $\mathrm{p}$. 879-900.

[65] Langham, J.A., N. Paulsen, and C.E. Hartel, Improving tax compliance strategies: Can the theory of planned behaviour predict business compliance. 2012. 10: p. 364.

[66] Davies, S.L., Using the Theory of Planned Behavior to Implement a Multi-Modal Fall Reduction Plan. 2019, Grand Canyon University.

[67] Sokolowski, J.A., Human behavior modeling: A real-world application. 2012: p. 26-92.

[68] Petrazycki, L. and A.J. Trevino, Law and morality. 2017: Routledge.

[69] Karjalainen, M., M. Siponen, and S. Sarker, Toward a stage theory of the development of employees' information security behavior. 2020. 93: p. 101782.

[70] Hunt, S.D., Strategic marketing, sustainability, the triple bottom line, and resource-advantage ( $R A)$ theory: Securing the foundations of strategic marketing theory and research. 2017. 7(1): p. 52-66.

[71] Lu, L.-C. and C.-J. Lu, Moral philosophy, materialism, and consumer ethics: An exploratory study in Indonesia. 2010. 94(2): p. 193-210.

[72] Hunt, S.D. and S.J. Vitell, The general theory of marketing ethics: A revision and three questions. 2006. 26(2): p. 143-153.

[73] Alexander, L. and M. Moore, Deontological ethics. 2007.

[74] Mandal, J., D.K. Ponnambath, and S.C. Parija, Utilitarian and deontological ethics in medicine. 2016. 6(1): p. 5.

[75] Paquette, M., E.J. Sommerfeldt, and M.L. Kent, Do the ends justify the means? Dialogue, development communication, and deontological ethics. 2015. 41(1): p. 30-39.

[76] Vitell, S.J. and S.D. Hunt, The general theory of marketing ethics: the consumer ethics and 
intentions issues, in Handbook on ethics and marketing. 2015, Edward Elgar Publishing.

[77] Holyoak, K.J. and D. Powell, Deontological coherence: A framework for commonsense moral reasoning. 2016. 142(11): p. 1179.

[78] Neher, W. and P. Sandin, Communicating ethically. 2015: Routledge.

[79] Zu, L., Purpose-driven leadership for sustainable business: From the Perspective of Taoism. 2019. 4(1): p. 1-31.

[80] O'Brien, J.J., Theoretical frameworks for ethical practice. 2019(5): p. 8.

[81] Hunt, S., Personal moral codes and the HuntVitell theory of ethics. 2016: p. 18.

[82] Khalid, K., et al., The millennial researchers' ethical decision model: A psychoanalytic approach. 2015. 21(5): p. 1256-1260.

[83] Ewing, G. and I. Demir, An ethical decisionmaking framework with serious gaming: smart water case study on flooding. 2020.

[84] Alonso-Coello, P., et al., GRADE Evidence to Decision (EtD) frameworks: a systematic and transparent approach to making well informed healthcare choices. 1: Introduction. 2016. 353.

[85] Crane, A., et al., Business ethics: Managing corporate citizenship and sustainability in the age of globalization. 2019: Oxford University Press, USA.

[86] Bornstein, A.M., et al., Reminders of past choices bias decisions for reward in humans. 2017. 8(1): p. 1-9.

[87] Sardanelli, D., et al., Lowering the pirate flag: a TPB study of the factors influencing the intention to pay for movie streaming services. 2019. 19(3): p. 549-574.

[88] Sang, Y., et al., Understanding the intentions behind illegal downloading: A comparative study of American and Korean college students. 2015. 32(2): p. 333-343.

[89] Rex, J., A. Lobo, and C. Leckie, Evaluating the drivers of sustainable behavioral intentions: An application and extension of the theory of planned behavior. 2015. 27(3): p. 263-284.

[90] Eisend, M., Morality effects and consumer responses to counterfeit and pirated products: A meta-analysis. 2019. 154(2): p. 301-323.

[91] Davidson, A., M.V. Nepomuceno, and M. Laroche, Shame on you: When materialism leads to purchase intentions toward counterfeit products. 2019.155(2): p. 479-494.

[92] Petrescu, M., J.T. Gironda, and P.K. Korgaonkar, Online piracy in the context of routine activities and subjective norms. 2018. 34(3-4): p. 314-346.

[93] Awang, Y., A.R.A. Rahman, and S. Ismail, The influences of attitude, subjective norm and adherence to Islamic professional ethics on fraud intention in financial reporting. 2019.

[94] Holt, T.J., R. Brewer, and A. Goldsmith, Digital drift and the "sense of injustice": Counter-productive policing of youth cybercrime. 2019. 40(9): p. 1144-1156.

[95] Davies, C., et al., The epistemological foundations of music piracy in the digital marketplace. 2015.9(4 (eng)).

[96] Perreault, G.P. and P. Ferrucci, What Is Digital Journalism? Defining the Practice and Role of the Digital Journalist. 2020. 8(10): p. 12981316.

[97] Teng, Y.-M., K.-S. Wu, and H.-H. Liu, Integrating altruism and the theory of planned behavior to predict patronage intention of a green hotel. 2015. 39(3): p. 299-315.

[98] Anggraini, F.R.R. and F.A.J. Siswanto, The role of perceived behavioral control and subjective norms to internal auditors' intention in conveying unethical behavior: A case study in Indonesia. 2016. 5(2): p. 141.

[99] Zhang, D., et al., Residents' waste separation behaviors at the source: Using SEM with the theory of planned behavior in Guangzhou, China. 2015. 12(8): p. 9475-9491.

[100] Alleyne, P., S. Soleyn, and T. Harris, Predicting accounting students' intentions to engage in software and music piracy. 2015. 13(4): p. 291-309.

[101] Chen, Y., X. Yan, and W. Fan, Examining the effects of decomposed perceived risk on consumer's online shopping behavior: A field study in China. 2015. 26(3): p. 315-326.

[102] Hu, L. and J.J. Pear, Effects of a selfinstructional manual, computer-aided personalized system of instruction, and demonstration videos on declarative and procedural knowledge acquisition of the assessment of basic learning abilities. 2016. 22(2): p. 64.

[103] Romiszowski, A.J., Designing instructional systems: Decision making in course planning and curriculum design. 2016: Routledge.

[104] Willis, D.P., K. Manaugh, and A. El-Geneidy, Cycling under influence: summarizing the influence of perceptions, attitudes, habits, and social environments on cycling for transportation. 2015. 9(8): p. 565-579. 
[105] Sheeran, P., et al., The impact of changing attitudes, norms, and self-efficacy on healthrelated intentions and behavior: a metaanalysis. 2016. 35(11): p. 1178.

[106] Herstein, R., et al., Anticounterfeiting strategies and their influence on attitudes of different counterfeit consumer types. 2015. 32(8): p. 842-859.

[107] Bhatia, V., Examining consumers' attitude towards purchase of counterfeit fashion products. 2018.

[108] Hair, J.F., et al., Multivariate data analysis 6th Edition. 2006, New Jersey: Prentice Hall.

[109] Kerlinger, F.N., Asas-asas Penelitian Behavioral (edisi Indonesia). 1998, Gadjah Mada University Press.

[110] Drost, E.A., Validity and reliability in social science research. 2011. 38(1): p. 105-123.

[111] Yoon, C., Theory of planned behavior and ethics theory in digital piracy: An integrated model. 2011. 100(3): p. 405-417.
[112] Cronan, T.P. and S. Al-Rafee, Factors that influence the intention to pirate software and media. 2008. 78(4): p. 527-545.

[113] Peace, A.G., D.F. Galletta, and J.Y. Thong, Software piracy in the workplace: A model and empirical test. 2003. 20(1): p. 153-177.

[114] d'Astous, A., F. Colbert, and D. Montpetit, Music piracy on the web-how effective are anti-piracy arguments? Evidence from the theory of planned behaviour. 2005. 28(3): p. 289-310.

\section{Creative Commons Attribution License 4.0 (Attribution 4.0 International, CC BY 4.0)}

This article is published under the terms of the Creative Commons Attribution License 4.0

https://creativecommons.org/licenses/by/4.0/deed.en US 